\title{
Water-rock interaction within the oligotrophic peat bog (part of the Vasyugan Swamp, Western Siberia)
}

\author{
Oleg Savichev ${ }^{1, *}$, Aleksey Mazurov ${ }^{1}$, Maxim Rudmin $^{1}$, and Evgeniya Soldatova ${ }^{1}$ \\ ${ }^{1}$ Tomsk Polytechnic University, School of Earth Sciences \& Engineering, Department of Geology, \\ 634050 Lenina ave 30, Russia
}

\begin{abstract}
Geochemical conditions of the formation of various minerals were studied within the oligotrophic pine-shrub and sphagnum peat bog. It was shown that at least two complex barriers function within the peat deposit. These barriers correspond to the changes in the advective and diffusion transfer of substances and promote the immobilization of $\mathrm{Fe}$ and a number of other chemical elements. The upper complex geochemical (redox, sulfide and sorption) barrier occurs approximately at the depths of 0.40 to $1.25 \mathrm{~m}$. The lower complex geochemical (alkaline and sorption) and mechanical barriers are located at the bottom part of the peat deposit (the depth of $2.25-2.50 \mathrm{~m}$ ).
\end{abstract}

\section{Introduction}

Peat bogs play a significant role in the functioning of biogeochemical cycles related to the climate and environmental changes, at least at the regional level. Particularly, the peat bogs are important in Western Siberia within the Ob river basin. During the evolution of wetland ecosystems, the removal of some substances intensifies, other substances, opposite, better accumulate in the solution. The results of the substances differentiation are manifested both across the area and to the depth of the peat bogs and affect the geochemical conditions [1-3]. This explains the need for the research of the mechanisms and regularities of the formation of the peat chemical and mineral composition in the Taiga zone of the Western Siberia. Various aspects of this issue have already been studied [2-4], however, a number of questions have been insufficiently covered, including the nature of the distribution of many chemical elements and the reasons of for the occurrence of some minerals in the peat bogs.

\section{Objects and methods}

Research was carried out on the example of the eastern part of one of the largest wetlands in the World - the Vasyugan Swamp (Western Siberia). This area is presented by the oligotrophic pine-shrub and sphagnum raised peat bog (hereinafter the regional term

\footnotetext{
*Corresponding author: osavichev@ mail.ru
} 
"ryam" is used) which are located within the watershed of the Klyuch and Gavrilovka Rivers. The description of the study area is given in $[5,6]$. The methods of research included: 1) sampling of the peat, organo-mineral sediments (OMS - the sediments containing from 15 to $50 \%$ of organic matter (of its dry mass)) and mineral soil; 2) laboratory analyses of the above mentioned substances; 3 ) calculation of the characteristics of water exchange within the ryam - filtration rates $(v)$ and hydrodynamic dispersion coefficients $(D)$, the calculation methods are given in $[7,8] ; 4)$ calculations of the saturation index $(S I)$ of a number of minerals and organo-mineral compounds based on the thermodynamic constants $\left(S I=\lg I A P-\lg K_{s p}\right.$, where $I A P$ is the product of the dissolved ions activities, $K_{s p}$ is the equilibrium constant), the calculation procedure is laid out in [9]; 4) statistical analysis of the data obtained using the MS Excel with a significance level of $5 \%$.

The sampling was carried out at the end of the winter period of 2017 (23.03.2017) in the point $\left(56.961^{\circ} \mathrm{N} ; 82.515^{\circ} \mathrm{E}\right)$ with the depth of the peat deposit of $2.50 \mathrm{~m}$. The samples were collected every $0.25 \mathrm{~m}$ to the deep. Laboratory analysis was done at the Tomsk Polytechnic University. In the aqueous extracts, the values of $\mathrm{pH}$ were measured by potentiometry and potassium permanganate demand by titrimetry. In the aqueous and acid extracts, the concentrations of 73 chemical elements were measured using an inductively coupled plasma mass spectrometry (NexION 300D, PerkinElmer, USA). Mineral inclusions in the peat and mineral composition of the underlying soil were analyzed by scanning electron microscopy. Studying the changes of the chemical composition of the extracts to the depth, the greatest attention was paid to $\mathrm{Ca}, \mathrm{Fe}, \mathrm{Al}$, and $\mathrm{Ce}$, because the content of $\mathrm{Ca}, \mathrm{Fe}, \mathrm{Al}$ reflects general mineralogical and geochemical conditions of the wetland ecosystems, whereas the content of Ce shows the specific features of trace elements accumulation. The research methodology is laid out in $[10,11]$.

\section{Results and discussion}

The mineral composition of the OMS and mineral soil of the ryam includes quartz, plagioclase, potassium feldspar, illite, chlorite, and calcite. Mineral inclusions in the peat are presented by Fe-hydroxides (oxides), quartz, phosphates of rare earth elements (REE), ilmenite, pyrite, galena, sphalerite and a number of other minerals.

Throughout the depth, the aqueous extracts are generally supersaturated with respect to quartz (Fig.) and undersaturated with respect to primary aluminosilicates and thus, water is able to dissolve aluminosilicates if there is available matter. The aforementioned conditions are typical not only for the underlying mineral soil but also for the active layer of the peat deposit which receives atmospheric aerosols and decomposition products of ryam vegetation. This fact is confirmed by an increase of the aqueous extract saturation with respect to mica and plagioclases at the depth of $0.00-0.25 \mathrm{~m}$, as well as an increase of the Si concentrations in the acid extracts (Table).

The nature and degree of interaction among free ryam water, aqueous extracts and mineral particles demonstrates strong influence of organic matter both directly, for example, due to the formation of poorly soluble compounds of humic acids with metals [12, 13], and indirectly, through the release of $\mathrm{CO}_{2}$, which is associated with the shift of carbonate equilibrium towards the precipitation of calcite (Fig.). Furthermore, the decomposition of organic matter under bacteria influence is accompanied by the formation of reducing conditions in the peat deposit. Such conditions lead to the formation of sulfide minerals, as confirmed both by the own materials (in particular, the inclusions of pyrite, sphalerite and galena are noted at the different depths of the inert horizon of the peat deposit) and by the research of other authors [4]. 
The analysis of the gathered data showed that the highest $\mathrm{Ca}$ content is noted in the acid extracts from the OMS (Table), where the calcite content can reach levels up to $16.6 \%$ and the saturation index of calcite and compounds with humic acids in the aqueous extract reaches maximum values. The highest $\mathrm{Fe}$ content is noted in the acid extracts from the bottom layer of the peat (the depth of 2.25-2.50 m) and from the mineral soil (2.75-3.00 $\mathrm{m})$, where glauconite, ilmenite and a number of other Fe-containing minerals are presented in addition to the $\mathrm{Fe}$-hydroxides (oxides). The maximum concentrations of $\mathrm{Al}$ are noted in the acid extracts from the OMS and the mineral soil. The elevated Al content, comparable to the values in the acid extracts from the bottom layer of the peat, is also found in the upper active layer of the peat deposit. It is also worth noting that the content of illite sharply increases (up to $44.8 \%$ ) simultaneously with the Al content, which likely indicates an intensification of Al-containing colloids formation. The highest Ce content is found in the acid extracts from the OMS and mineral soil, in which sorption and coprecipitation on iron and phosphorus compounds may predominate.

Table. Chemical composition of the aqueous and acid extracts from the peat, organo-mineral sediments (OMS) and mineral soil of the ryam area.

\begin{tabular}{|l|c|c|c|c|c|c|c|c|c|c|c|}
\hline \multirow{2}{*}{ Depth interval, $\mathrm{m}$} & $\mathrm{pH}$ & $\mathrm{PD}$, & $\mathbf{C a}$ & $\mathbf{S}$ & $\mathbf{A l}$ & $\mathbf{S i}$ & $\mathbf{P}$ & Fe & Ce \\
\cline { 4 - 10 } & & $\mathrm{mgO}_{2} / \mathrm{L}$ & \multicolumn{6}{|c|}{ Concentration in the aqueous extracts, $\mathrm{mg} / \mathrm{kg}$} \\
\hline $0-0.25$ (mat, peat) & 4.63 & 160.0 & $\frac{34.2}{2256}$ & $\frac{31.2}{1134}$ & $\frac{8.7}{1208}$ & $\frac{20.8}{916}$ & $\frac{29.7}{383}$ & $\frac{8.1}{1730}$ & $\frac{0.006}{1.6}$ \\
\hline $0.25-0.50$ (peat) & 4.65 & 117.0 & $\frac{30.5}{1844}$ & $\frac{21.1}{2402}$ & $\frac{5.9}{958}$ & $\frac{16.3}{1041}$ & $\frac{18.7}{356}$ & $\frac{3.4}{686}$ & $\frac{0.005}{1.1}$ \\
\hline $0.50-0.75$ (peat) & 4.59 & 72.8 & $\frac{20.8}{2161}$ & $\frac{3.3}{1448}$ & $\frac{2.8}{499}$ & $\frac{17.2}{396}$ & $\frac{10.7}{237}$ & $\frac{3.1}{523}$ & $\frac{0.002}{0.51}$ \\
\hline $0.75-1.00$ (peat) & 4.58 & 94.7 & $\frac{33.0}{3225}$ & $\frac{4.4}{1576}$ & $\frac{3.3}{355}$ & $\frac{15.9}{613}$ & $\frac{13.3}{220}$ & $\frac{3.3}{763}$ & $\frac{0.005}{0.35}$ \\
\hline $1.00-1.25$ (peat) & 4.56 & 88.2 & $\frac{58.7}{3398}$ & $\frac{17.3}{1594}$ & $\frac{3.0}{376}$ & $\frac{21.1}{681}$ & $\frac{14.2}{179}$ & $\frac{4.1}{625}$ & $\frac{0.003}{0.34}$ \\
\hline $1.25-1.50$ (peat) & 4.56 & 101.1 & $\frac{65.1}{7316}$ & $\frac{10.4}{2134}$ & $\frac{2.4}{749}$ & $\frac{22.8}{232}$ & $\frac{14.0}{622}$ & $\frac{3.5}{1420}$ & $\frac{0.003}{0.90}$ \\
\hline $1.50-1.75$ (peat) & 4.90 & 108.4 & $\frac{113}{12787}$ & $\frac{7.4}{2203}$ & $\frac{1.6}{601}$ & $\frac{18.5}{151}$ & $\frac{7.7}{420}$ & $\frac{5.1}{2875}$ & $\frac{0.001}{0.79}$ \\
\hline $1.75-2.00$ (peat) & 5.38 & 128.0 & $\frac{117}{17823}$ & $\frac{2.0}{2712}$ & $\frac{1.3}{809}$ & $\frac{19.0}{173}$ & $\frac{4.2}{554}$ & $\frac{5.5}{3860}$ & $\frac{0.001}{1.13}$ \\
\hline $2.00-2.25$ (peat) & 5.47 & 133.8 & $\frac{192}{20278}$ & $\frac{10.4}{2515}$ & $\frac{1.3}{688}$ & $\frac{22.2}{222}$ & $\frac{5.2}{369}$ & $\frac{7.7}{4656}$ & $\frac{0.001}{0.80}$ \\
\hline $2.25-2.50$ (peat) & 6.04 & 65.6 & $\frac{149}{30100}$ & $\frac{1.3}{2015}$ & $\frac{7.5}{3030}$ & $\frac{30.0}{318}$ & $\frac{0.7}{491}$ & $\frac{10.8}{7804}$ & $\frac{0.007}{8.8}$ \\
\hline $2.50-2.75$ (OMS) & 8.06 & 10.6 & $\frac{148}{57992}$ & $\frac{3.0}{260}$ & $\frac{10.7}{5599}$ & $\frac{29.4}{2218}$ & $\frac{0.2}{255}$ & $\frac{7.4}{6708}$ & $\frac{0.007}{26.3}$ \\
\hline $2.75-3.00$ (soil) & 8.10 & 9.8 & $\frac{148}{45174}$ & $\frac{1.6}{224}$ & $\frac{21.3}{7795}$ & $\frac{55.8}{2193}$ & $\frac{0.2}{268}$ & $\frac{14.5}{12552}$ & $\frac{0.011}{27.4}$ \\
\hline
\end{tabular}

Notes: PD - permanganate demand; $\mathrm{pH}$ and PD were measured in the aqueous extracts.

The concentrations of $\mathrm{Ca}, \mathrm{Fe}$ in the aqueous and acid extracts are mainly in direct relation with the value of potassium permanganate demand, whereas the $\mathrm{Al}$ and $\mathrm{Ce}$ content in the aqueous and acid extracts decreases in the samples with higher potassium permanganate demand values (Table). 
The noticeable effect of advective transfer on the distribution of the chemical elements with the depth is manifested mainly in the depths of up to $1.00-1.25 \mathrm{~m}$ (Fig.), below which the reducing conditions likely prevail according to the sharp increase in the total content of sulfur in the acid extracts (Table) and the published research [5]. Fluctuations in the water level of the studied ryam are usually within the limits of the depth of $0.20-0.40 \mathrm{~m}$, which makes it possible to approximate the boundaries of the complex redox, sulfide and sorption (hydroxide) barrier in the peat deposit at the depths of 0.40 to $1.25 \mathrm{~m}$. This barrier affects, first of all, the content of $\mathrm{Fe}$ and $\mathrm{S}$ in the acid extracts.

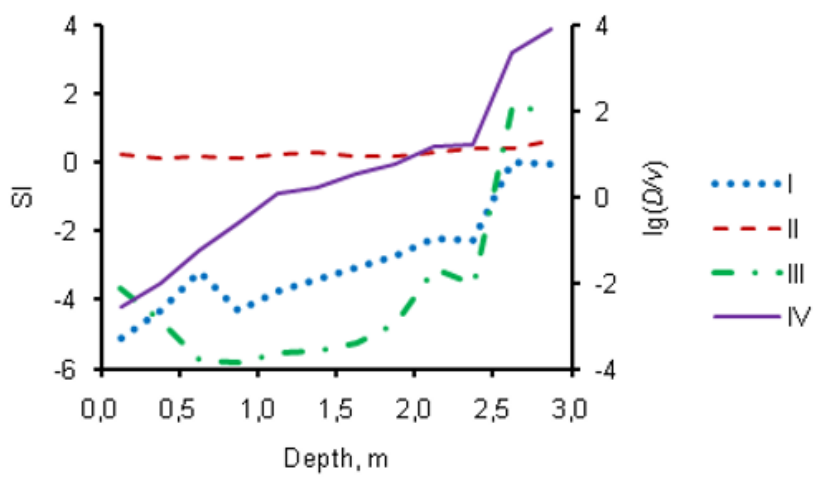

Fig. The changes of the saturation index SI (I-III) and the logarithm of the ratio of the hydrodynamic dispersion coefficient $D$ to the vertical filtration rate $v$ (IV) with the depth.

Reactions: $\mathrm{I}-\mathrm{CaCO}_{3}$ (calcite) $+\mathrm{CO}_{2}+\mathrm{H}_{2} \mathrm{O}=\mathrm{Ca}^{2+}+2 \cdot \mathrm{HCO}_{3}{ }^{-} ; \mathrm{II}-\mathrm{SiO}_{2}$ (quartz) $+2 \cdot \mathrm{H}_{2} \mathrm{O}=\mathrm{H}_{4} \mathrm{SiO}_{4}{ }^{0} ; \mathrm{III}-$ $2 \cdot \mathrm{KAl}_{3} \mathrm{Si}_{3} \mathrm{O}_{10} \mathrm{OH}_{2}$ (muscovite) $+2 \cdot \mathrm{H}^{+}+3 \cdot \mathrm{H}_{2} \mathrm{O}=3 \cdot \mathrm{Al}_{2} \mathrm{Si}_{2} \mathrm{O}_{7} \cdot 2 \cdot \mathrm{H}_{2} \mathrm{O}$ (kaolinite) $+2 \cdot \mathrm{K}^{+}$.

Another barrier is complex alkaline (carbonate and hydrolytic) and sorption (hydroxide, clay and carbonate) barrier which occurs at the bottom part of the peat deposit and corresponds to a relatively sharp decrease in the filtration properties of the peat at the depth of 2.25-2.50 m along with a sharp increase in the $\mathrm{pH}$ values (Table). It can be concluded that at the boundary between the peat deposit and the mineral soil within the main part of the ryam, not only advective, but also diffusion transport of substances noticeably decreases. In this case, the changes in the concentrations of the chemical elements in the acid and aqueous extracts are mainly controlled by dissolution-precipitation and sorptiondesorption processes. Consequently, not only the complex geochemical but also the mechanical barrier functions at the bottom boundary of the peat deposit.

The presence of the latter barrier is probably related not only with a decrease in the filtration coefficients of the bottom loams but also with the formation of modern secondary minerals in the lower part of the peat deposit. The statistically significant direct relationship between the ratio $D / v$ and $S I$ of a number of minerals confirms this statement. The correlation coefficients between $D / v$ and $S I$ of carbonates, quartz, and a number of aluminosilicates vary from 0.71 to 0.86 . It should be noted that, in addition to the precipitation of calcite from an aqueous solution, the formation of kaolinite (Fig.) and the transformation of smectite group minerals which are presented in the underlying soils, dry lands, and atmospheric aerosols play an important role in the formation of the mechanical barrier [14].

\section{Conclusions}

Thus, the functioning of two barriers in the peat deposit associated with a relatively sharp change in the geochemical conditions and filtration properties of the peat and mineral soil 
adequately explains the distribution of the studied chemical elements in the aqueous and acid extracts from the peat, OMS, and mineral soil. The upper barrier occurs approximately at the depth of 0.40 to $1.25 \mathrm{~m}$ and corresponds to the formation of reducing conditions and the advective transfer of substances in the peat deposit. The lower barrier (mechanical and complex geochemical) occurs at the bottom boundary of the peat deposit (the depth of $2.25-2.50 \mathrm{~m}$ ). The latter barrier is characterized by an additional deterioration of soil filtration properties and diffusion transfer. The result of the functioning of the upper barrier is the formation of Fe hydroxides and phosphates of REE in the peat deposit. At the same time, local precipitation of clay minerals, sulfides of iron and some other metals occurs within the geochemical gradient between the areas with oxidizing and reducing conditions. Due to the influence of the lower barrier at the bottom part of the peat deposit, the intensity of formation and/or accumulation of clay minerals increases. In addition, because of autotrophic sulfate reduction under the absence of dissolved oxygen the $\mathrm{pH}$ values increase and thus, the precipitation of calcite and hydroxides of certain metals occurs.

The research was supported by the Government of the Russian Federation (contract No 14.Z50.31.0012) and the Russian Foundation for Basic Research (projects No 18-05-00302, No 1705-00042, No 18-55-80015). The study of humic acids in the aqueous extracts was funded by the Russian Science Foundation (project No 17-77-10017).

\section{References}

1. O.L. Liss, L.I. Abramova, N.A. Avetov, Bolotnye sistemy Zapadnoy Sibiri i ikh prirodookhrannoe znachenie [Bog of Western Siberia and their conservation value] (Grif i K ${ }^{\circ}$ Publ., Tula, 2001) In Rus.

2. T. Minayeva, W. Bleuten, A. Sirin, E.D. Lapshina, Wetl. and Nat. Res. Manag. Ecol. Stud., 190, 315-341 (2006)

3. W. Shotyk, Environ. Rev., 4, 149-183 (1996)

4. A.M. López-Buendía, M.K.G. Whateley, J. Bastida, M.M. Urquiola, Int. J. of Coal Geol., 71, 246-262 (2007)

5. L.I. Inisheva, T.V. Dement'yeva, Ye.A. Golovatskaya, Ye.V. Porokhina, Nauchnoissledovatel'skiy poligon "Vasyugan'ye». Programma nauchnoy ekskursii. [Scientificresearch ground "Vasyugane". Program of scientific excursion] (TSNTI, Tomsk, 2003) In Rus.

6. O.G. Savichev, A.K. Mazurov, Bull. of Tom. Polyt. Univ. Geo As. Eng., 329, 38-48 (2018) In Rus.

7. Ye.M. Gusev, O.N. Nasonova, Modelirovaniye teplo- $i$ vlagoobmena poverkhnosti sushi s atmosferoy [Modelling of warm and moisture exchange of a land surface with an atmosphere] (Nauka, Moscow, 2010) In Rus.

8. O.G. Savichev, Probl. of Ecol., 8, 118-124 (2015)

9. O.G. Savichev, O.V. Kolokolova, E.A. Zhukovskaya, Geoekol., 2, 108-119 (2003) In Rus.

10. M. Rudmin, A. Ruban, O. Savichev, A. Mazurov, A. Dauletova, and O. Savinova, Minerals, 8, 500, 1-13 (2018)

11. O.G. Savichev, A.K. Mazurov, M.A. Rudmin, A.A. Hvashchevskaya, A.B. Dauletova, Bulletin of the Tom. Polyt. Univ. Geo As. Eng., 9, 329, 101-116 (2018) In Rus.

12. J.H. Ephraim, B. Allard, Metal Ion Binding by Humic Substances. Modelling in Aquatic Chemistry, 207-244 (OECD, Nuclear Energy Agency, Paris, 1997)

13. S.R. Kraynov, B.N. Ryzhenko, V.M. Shvets, Geokhimiya podzemnykh vod: teoreticheskie, prikladnye i ekologicheskie aspekty [Geochemistry of ground waters: theoretical, applied and environmental aspects] (Nauka, Moscow, 2004) In Rus. 
14. P.P. Timofeyev, L.I. Bogolyubova, Geokhimiya organicheskogo veshchestva golotsenovykh otlozheniy $v$ oblastyakh primorskogo torfonakopleniya [Geochemy of organic substance of the holocene deposits seashore areas of peat accumulation] (Nauka, Moscow, 1999) In Rus. 